\title{
Analysis of China's Supply-side Structural Reform
}

\author{
Sun Yexia \\ Northeast Normal University \\ People Street No. 5268, Changchun, Jilin Province, China
}

\author{
Zhang Liang \\ People's Bank of China Changchun Center Branch \\ People Street No. 2219, Changchun, Jilin Province, China
}

\begin{abstract}
The supply-side structural reform is a major decision, which is made in the macro context of the Chinese economy entering a new normal. The question is based on five major problems, such as the imbalance of regional development and urban and rural development, the insufficient power of industrial structure upgrading, etc. In order to deepen the supply-side structural reform, China, from the policy, has mainly done the following work. Firstly, a proactive fiscal policy and a prudent monetary policy have been retained to implement to create a stable macro-economic environment. Secondly, the industrial policy of accelerating to transform to the tertiary industry has been carried out. Thirdly, the market environment has been improved, and the market vitality and consumer potential have been stimulated. By the first half of 2018, China's supply-side structural reform has achieved some concrete achievements.
\end{abstract}

Keywords-supply-side structural reform, industrial policy, economic growth

\section{PROPOSAL FOR SUPPLY-SIDE STRUCTURAL REFORM}

On November 10, 2015, General Secretary Xi Jinping presided over the eleventh meeting of the Central Financial and Economic Leading Group to study economic structural reform and urban work. Xi Jinping pointed out, "while moderately expanding aggregate demand, supply-side structural reform should be put forth effort to strengthen, and the quality and efficiency of the supply system should be focused on improving.” On January 27, 2016, the 12th meeting of the Central Financial and Economic Leading Group studied the supply-side structural reform program. On October 18, 2017, in the report of the 19th National Congress, Comrade Xi Jinping pointed out deepening the supply-side structural reform. To build a modern economic system, the point of the development of the economy must be focused on the real economy, and the main direction is to improve the quality of the supply system, significantly enhancing China's economic quality advantages [1].

From the international situation, since 2008, due to the impact of the economic crisis, the golden economic growth period of western developed countries has come to the end, which has reduced the effective demand. Other trade protectionism and countervailing and strict requirements in market access have led to continuous trade friction, and these problems have in some degree affected China's trade. On the other hand, the changes in the domestic situation are mainly divided into two points: Firstly, economic development has entered the new normal. Secondly, China's principal contradictions have changed.
The supply-side structural reform was proposed after years of demand-side reforms. China's market-oriented reforms are, to a certain extent, demand-side reforms. On the basis of years of demand-side reforms and their significant results, the problems to be solved on the demand-side are mainly to improve and enrich demand-side management issues under the new system, including improving the demand for consumption, investment and export the troika to promote the demandoriented mechanism of economic growth, improve the mechanism of fiscal and monetary policy adjustment aggregate demand. The necessity of China's supply-side structural reform is related to the basic judgment of the current economic downturn. Although the economic depression does not rule out the problem of insufficient effective demand, the main aspect of the contradiction is on the supply side. The current economic recession does not entirely belong to a cyclical issue, but a structural issue on the supply side. If it is a cyclical problem, we can wait for the economic recovery, but the problem now is that there is a large amount of surplus and inefficient capacity that cannot form an effective supply. This will drag down the economic recovery. High leverage and high cost will not only make many enterprises become zombies without vitality, but also cause excessive local debt to many local governments. Therefore, if the supply side problem cannot be solved, the economic situation will be difficult to rally.

\section{THE PROBLEMS CHINA'S ECONOMIC GROWTH FACES}

\section{A. The imbalance of regional development and urban and rural development directly affects the improvement of regional competitiveness.}

The public service level in the central and western regions and rural areas still has a significant gap with the eastern regions and urban areas, and most of the public services are attached to the household registration. It has already affected the formation of the national unified factor market, and the regional and urban-rural imbalances have produced selfreinforcing endogenous mechanism. This pattern determines that China enters the new normal, but it does not mean that all regions and urban and rural areas are simultaneously entering the new normal. The vast central and western regions and rural areas still have very broad financial investment space, and the potential economic growth capacity is relatively sufficient. However, the development of these areas cannot simply repeat the "story of yesterday". It is necessary to play a "learning effect" to avoid negative problems in the eastern regions and urban areas, and to actively optimize supply side while expanding demand. 
B. Industrial structure upgrading driving force is insufficient, and the overall innovation capacity of the industry is still at a low level, so the competitiveness of industrial structure has been restrained.

China is at an important point in accelerating industrialization and transforming into a knowledge society. However, almost all the traditional industries have crises, the administrative monopoly of state-owned enterprises is very prominent, the innovation degree of industrial networking is relatively low, the mechanism of knowledge diffusion and sharing is not perfect, the vitality of market entities is insufficient, the willingness to invest is not strong, and the expectation of the market subject to the economy is from optimism to wait-and-see attitude and even pessimism [2]. It has seriously affected China's transitional process from agricultural civilization to industrial civilization and further to knowledge civilization. Some traditional endowment advantages are gradually lost. It is necessary to find a new way to optimize production methods, to make technological innovation costs more "low-cost", implement state-owned enterprise reforms, and stimulate market vitalities.

\section{The transition from a planned economy to a market} economy has entered a crucial period, and the institutional factors that constrain economic transformation and upgrading still exist, and the institutional structure competitiveness needs to be improved.

The relationship between the government and the market and society is still not properly handled. When the government treats the relationship with the market and society, it still fills with the "control" thinking instead of establishing an equal "cooperative relationship". It is a very serious situation where the government intervenes the market and society. When enterprises and social entities develop the markets and allocating resources, they do not think of "finding the market" and "finding the demand", but "finding the government" and achieving the stated objectives through a strong government.

\section{Reform and opening up will enter a new stage, and it is still necessary to explore multiple ways and organically integrate supply-side management and new forms of opening up to build a global-oriented benefit-sharing structure and improve the competitiveness of interest structures.}

Before the new economic normal, the export-oriented strategy was an important strategy to stimulate China's economic growth, attracting a large amount of foreign investment and improving the situation of China's capital shortage. However, this kind of large inflows and outflows opening-up model has intensified the tension between global resources and energy supply, and has triggered interest conflicts between China and resources and energy producing areas. China should speed up the construction of a new open economic pattern, coordinate the "bringing" and "going out", balance industrial upgrading and transfer, strengthen manufacturing industry and service industry, and serve the overall situation of China's comprehensive deepening reform. In this sense, the "Belt and Road" and the AIIB are not a regional and partial concept, but to create a new mechanism for benefit co-sharing and cooperation.

\section{E. The advantages of China's traditional rural social governance model are constantly being lost.}

The traditional ethical structure related by family has been severely affected. It is urgent to perfect the social ethical structure and serve the supply side management in accordance with the concept of promoting national governance modernization.

\section{THE SPECIFIC MEASURES FOR THE SUPPLY-SIDE STRUCTURAL REFORM}

\section{A. Macroeconomic policies should be stable and a stable macroeconomic environment should be created.}

A proactive fiscal policy and a prudent monetary policy will be implemented, which can work together. The specific requirements of the 2015 Central Economic Work Conference on the 2016 macroeconomic policy have released an important signal for creating a stable macroeconomic environment for the supply-side structural reform.

At present, the world economy and trade are sluggish, the global market turmoil has deepened its influence on China, and the deep contradiction between China and the world has become superimposed. The difficulties in the real economy have increased, and the dilemmas faced by macro-control have added. Since 2015, under the strong leadership of the Party Central Committee and the State Council, through the strengthening of targeted regulation and well-timed regulation, structural reforms have been used to promote structural adjustment, effective measures have been implemented to stabilize the market, and new kinetic energy has been bred and formed. Employment expansion, income growth and environmental improvement have brought a lot of benefits to the masses. In this process, the contributions of active fiscal policy and prudent monetary policy cannot go unnoticed.

\section{B. The industrial policy must be accurate and the structural reform direction should be positioned accurately.}

In recent years, China's overall economic structure has been continuously optimized, and economic development is transiting to a tertiary industry-led pattern acceleratedly. However, while the industrial structure has improved significantly, structural contradictions remain outstanding. On the one hand, the promotion potential of the tertiary industry is still very large. Compared with the proportion of more than $70 \%$ of the tertiary industry in the developed countries such as Europe and the United States, the share of China's tertiary industry in the total economic output is still very low, which is less than $50 \%$. On the other hand, there are many traditional industries in China's industrial system, the growth of emerging industries is difficult to make up for the sluggishness of traditional industries, and the internal structure contradictions are quite obvious. The Central Economic Work Conference proposes strengthening the supply-side structural reform, focus on improving the quality and efficiency of the supply system, and enhance the driving force for sustained economic 
growth. This has become a showcase for China's future industrial restructuring policy [3].

The internal structure of the tertiary industry has perfected markedly, the overall level has improved dramatically, and the service sector has continued to expand, gradually becoming one of the main driving forces for China's economic growth. The financial industries and the real estate industries have become the principal forces driving the development of the tertiary industry. The proportion of the traditional service industry has declined in the tertiary industry. The modern service industries such as financial insurance, computer service, logistics and distribution have developed rapidly. The new service industries such as socialized pension, leisure tourism and community service are being paid more and more attention.

\section{Micro-level policy injects dynamism into the economy. Corporate vitality and consumption potential need to be stimulated.}

The 2015 Central Economic Work Conference clearly stated, "Micro-level policy injects dynamism into the economy”. How to achieve a flexible micro policy? It is to improve the market environment, stimulate market vitality and consumer potential, enliven the policy to inject the microeconomy, fully release the production and consumption vitality and internal growth potential, and create a new economic development situation. The micro-economy is the "barometer" of the economic situation and the "propeller" of development. The micro policy is a realistic demand for responding to downward pressure on the economy and accumulating and developing new driving forces. It is essential to accelerate the structural reform of the supply side and realize the transformation and upgrading of China's economic development by enlivening micro policy and improving quality and efficiency.

The micro-market player is the creator of social wealth and the inexhaustible source of the endogenous power of economic progress. From the current situation of China, one of the key factors that the market vitality has not been fully stimulated is that the government has interfered too much with the market players. Therefore, an important way to reach the policy goal that micro-level policy injects dynamism into the economy is to speed up simplifying administrative procedures and promoting the transformation of government functions. In accordance with the deployment requirements of the Party Central Committee and the State Council, the transformation of government functions should be based on the basic idea of "streamlining administration and delegating power, combining power delegation with effective oversight and optimizing service”, putting down what should be put down, managing well what should be managed, and serving in place what should be served. And then "turning on the water pisciculture" and enlivening the micro-economy can be achieved truly.

\section{THE EFFECTIVENESS OF THE SUPPLY-SIDE STRUCTURAL REFORM}

China's supply-side structural reforms have been solidly carried forward into the effect. From the de production capacity, the key industries such as steel and coal industries exceeded the annual planning tasks in 2017. From the de-stocking, commercial housing areas for sale have dropped significantly. From the de-leveraging, the debt ratios of the corporate sector have been steadily decreasing, and the deactivation and deficiency of funds have been contained, which are conducive to better serving the real economy. From the cost reduction, the taxes and dues costs, land costs, logistics costs, financing costs and institutional transaction costs of enterprises have declined to varied degrees. From the supplementing the shortcoming, we have effectively improved the investment in weak links as well as weak links in economic and social development such as ecological protection, environmental governance, infrastructure innovation, scientific and technological innovation, people's livelihood construction, water conservancy management, and the primary industry.

On June 27, 2018, the financial data of industrial enterprises released by the National Bureau of Statistics showed that in the first five months of this year, the total profits of industrial enterprises above designated size reached 729.83 billion Yuan, with a year-on-year increase of $16.5 \%$, and the growth rate was faster than that in January to April with 1.5 percentage points. Among them, the profit of industrial enterprises in May increased by $21.1 \%$ year-on-year, which was 0.8 percentage points slower than that in April, and went ahead with the momentum of rapid growth. The above data reflects the efficiency of Chinese industrial enterprise has been overall improved. With the gradual effective implementation of policies such as "capacity reduction, de-stocking, deleveraging, cost reduction, and improving underdeveloped area”, China’s supply-side structural reforms have achieved positive results.

\section{A. The cost reduction leverage was reduced.}

In terms of industries, from January to May, the mining industry realized a total profit of 233.36 billion Yuan, a yearon-year increase of $41.6 \%$; the manufacturing industry realized a total profit of 2,315.01 billion Yuan, an year-on-year increase of $13.8 \%$; the power, heat, gas and water production and supply industries realized a total profit of 181.46 billion Yuan, a yearon-year increase of $26.1 \%$. The effect of supply-side structural reforms in China's industrial sector is continuously obvious. More specifically, the one hand was the cost reduction. From January to May, the cost per 100 Yuan of the main business income of industrial enterprises above designated size was 92.59 Yuan, a year-on-year decrease of 0.35 Yuan. Among them, the cost per 100 Yuan of main business income was 84.49 Yuan, a year-on-year decrease of 0.31 Yuan. The other hand, the leverage ratio was reduced. At the end of May, the asset-liability ratio of industrial enterprises above designated size was $56.6 \%$, a year-on-year decrease of 0.6 percentage points. Among them, the asset-liability ratio of state-owned holding corporations was $59.5 \%$, a year-on-year decrease of 1.5 percentage points, and the de-leveraging effect of state-owned enterprises was more significant [4].

The data show that China's promotion of supply-side structural reform has achieved positive results, and policy measures such as capacity reduction, de-stocking, deleveraging and cost reduction have been effectively implemented. Taking capacity reduction as an example, its fundamental role is to 
optimize the market competition environment. In the past, many industries in China were in an excessively competitive state, and the profitability of enterprises was very weak. Capacity reduction made the market competition to be optimized, and further the profitability of enterprises was improved, which was prominently reflected in industries with excessive overcapacity such as coal and steel industries. The efficiency of industrial enterprises has been on an overall continuous improvement. On the one hand, the turnover of finished goods inventory has accelerated. At the end of May, inventory turnover days of finished products of industrial enterprises above designated size were 16.6 days, a year-onyear decrease of 0.2 days. On the other hand, corporate profitability has increased significantly. From January to May, the profit margin of the main business of industrial enterprises above designated size was $6.36 \%$, a year-on-year increase of 0.35 percentage points.

\section{B. Profits maintained rapid growth.}

The data show that, in May, industrial enterprises above designated size achieved a total profit of 607.06 billion Yuan, a year-on-year increase of $21.1 \%$, which was 0.8 percentage points slower than that in April. Rising prices and falling costs promoted the profit of industrial enterprises in May to maintain a rapid growth momentum. Although the industrial profit growth rate in May was a little lower than that in April, it still maintained rapid growth. In addition to the cost reduction factor, it also benefited from the price increase. In terms of price changes, the ex-factory price of industrial producers rose in May, a year-on-year increase of $4.1 \%$, this was 0.7 percentage points higher than that in April. Industrial producers' purchase prices also rose in May, a year-on-year increase of $4.3 \%$, which was 0.6 percentage points higher than that in April. According to preliminary estimates, the price changes in May have a $4.3 \%$ increase in profit growth than that in April.

The data demonstrate that, from January to May, the source of profit growth was mainly in the raw materials processing and utilization industries such as steel, building materials and chemicals. Industries with more added profits were mainly ferrous metal smelting and calendaring industries, with a profit increase of 1.1 times. Non-metallic mineral products industry profits increased by $44.6 \%$. And the profit of chemical raw materials and chemical products manufacturing industries increased by $27.7 \%$. Oil and natural gas mining industry profits growth rate was 2.6 times. And the profits of electric power production and supply industry increased by $27.8 \%$. These five industries contributed nearly $70 \%$ to the profit growth of all industrial enterprises above designated size. Industrial performance of the industrial enterprises operation was sound in May with the improvement of industrial performance in April. In the current situation of stable prices, the profits of industrial enterprises will maintain a rapid growth momentum. It is expected that the production and operation status of industrial enterprises in the second quarter will be better than that in the first quarter. In the context of supply-side reform, supply and demand in the industrial sector have been improved. From a macro perspective, downstream consumption data have risen steadily, while the growth rate of total exports has rebounded sharply, and the demand has stabilized. The broken line in the fig. 1 represents the year-on-year bases of the total retail sales of social consumer goods in the month, and the bar chart data represent the numerical values of the total monthly retail sales of social consumer goods.

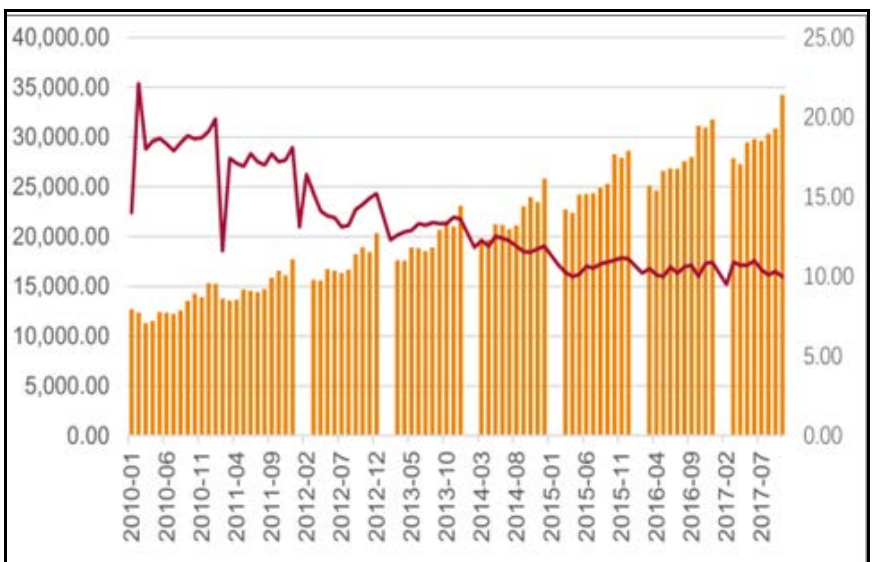

Fig. 1. Total retail sales of social consumer goods

\section{CONCLUSION}

In the new era, a new background has emerged in China, that is, the new normal of economic development and the transformation of major contradictions. Deepening the supplyside structural reform can correctly handle the main contradictions existing in China, correctly promote the current economic development directions of China, transform the transformation of economic development drivers, and enhance the development of manufacturing industries. China has had multi-faceted reforms, and has put the supply-side structural reforms into practice. Firstly, a proactive fiscal policy and a prudent monetary policy have been kept to implement to create a stable macroeconomic environment. Secondly, the industrial policy of accelerating to transform to the tertiary industry has been carried out. Thirdly, the market environment has been improved, and the market vitality and consumer potential have been stimulated. China's supply-side structural reform has achieved a series of achievements.

\section{REFERENCES}

[1] Y. Hong. Cultivate New Kinetic Energy: an Upgraded Version of the Supply-side Structural Reform, Economic Science, No. 6, 2018.

[2] T. Zhou. Supply Side Structural Reform and Modern Economic System Construction, Time finance, No.5, 2018.

[3] Accelerate the Transformation of Government Functions and Promote Supply-side Structural Reform, People Daily, October 26, 2016.

[4] X. Liu. Promote Supply Side Structural Reform towards the goal of Insurance and Powerful Nation, Financial Times, July 6, 2016. 